\title{
The Garden and the Gardeners of the Deep
}

\section{Sharon Pradhan*}

Graduate Student of Department of Zoology, Ravenshaw University, India

*Corresponding Author: Sharon Pradhan, Graduate Student of Department of Zoology, Ravenshaw University, India.
Received: November 17, 2021

Published: December 29, 2021

(C) All rights are reserved by Sharon Pradhan.

\section{Introduction}

When we usually think about the term "garden", beautiful plants, colourful flowers, different shades of brown soil and sunlight comes to our mind. You all must be wondering what I mean about the term 'garden and the gardeners of the deep'. Some might even start thinking that can even garden grow under the sea.

Yes, it absolutely can. Instead, some beautiful gardens exist under the waters only.

All gardens are made up of plants, but this garden is made up of only animals. Animals are the sole builders of this garden, and they make this garden so much more beautiful.

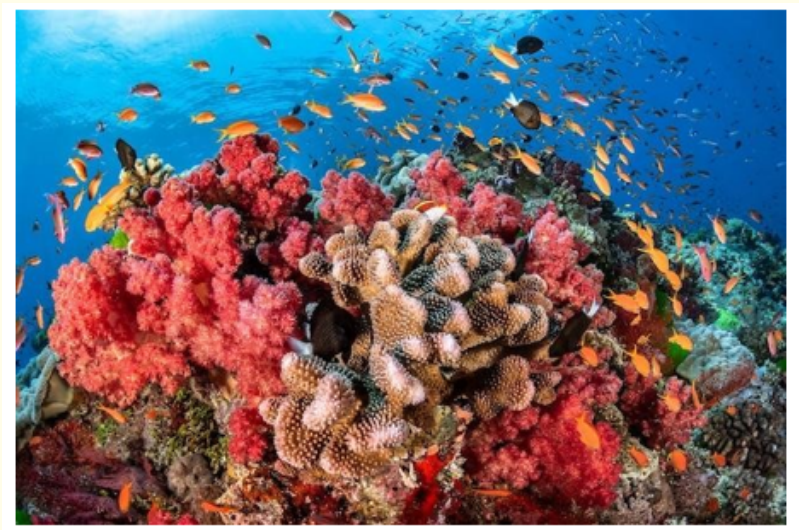

Figure 1: Picture credits: Greg Lecoeur. Source: National Geographic.
The garden which I'm talking about is a Coral Reef. The coral reefs are the most diverse ecosystems of our world. About $0.1 \%$ of the total ocean floor covered by coral reefs but they house about $25 \%$ of the total species available in the ocean. This shows how diverse they are.

The reefs or the 'gardens of the deep' are primarily made up of corals that belong to the class Anthozoa of the phylum Cnidaria. This phylum is also the home of sea anemones, jellyfishes, hydras, etc. Corals are the primary

reef builders because of their ability to secrete calcium carbonate that makes a hard exoskeleton around them. They mostly grow well in the warm shallow seas of the tropics.

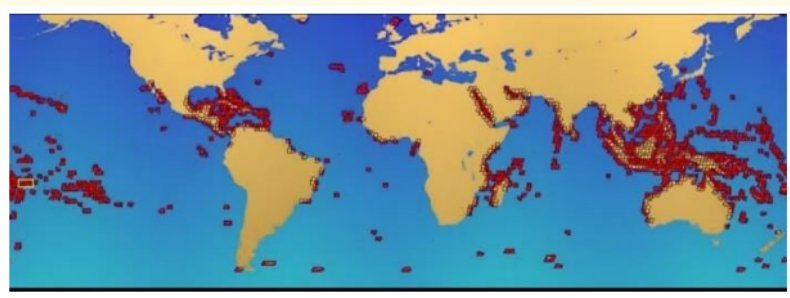

Figure 2: Distribution of coral reefs across the globe [1].

\section{Formation}

Most coral reefs are less than 10,000 years old since they were formed during the Last Glacial Period. They are found away from the continental shelves, around oceanic islands and atolls. Some of 
them are volcanic in origin. According to Spalding., et al. there are around 5 main varieties of coral reefs viz. the fringing reef, barrier reef, atoll, bank reef, platform reef and patch reef etc.

The most famous reefs of the world are The Great Barrier Reef, Australia, Somosomo Strait, Fiji, Baros and North Male Atoll, Maldives to name a few.

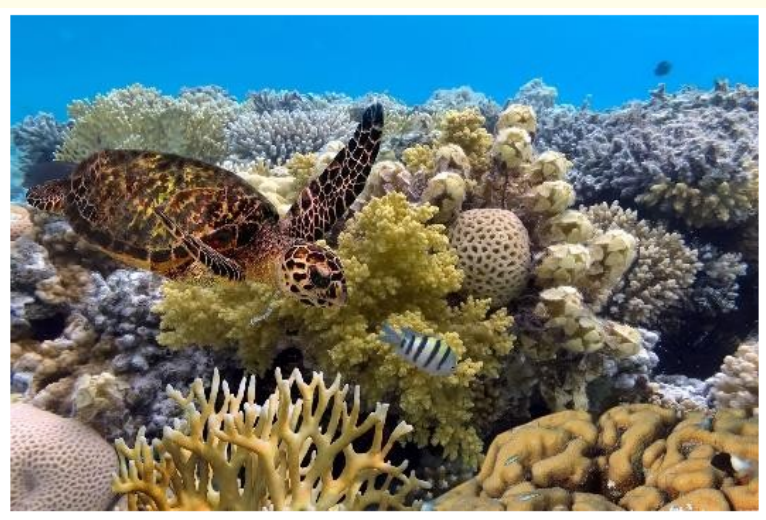

Figure 3: The Great Barrier.

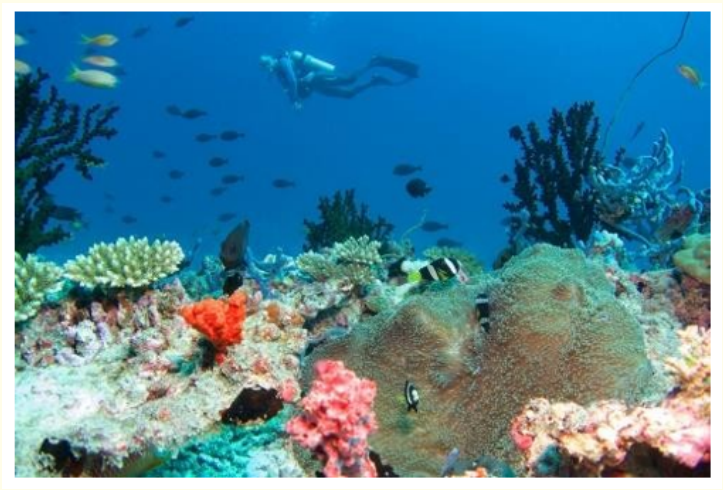

Figure 4: Baros and North Male Atoll, Maldives.

The different types of gardeners:

Corals

\section{Madrepora}

They are commonly known as stag-horn coral because it looks like the horn of a stag. They belong to the group of stony corals, and they are the primary reef builders. This is the most common type found in the Great Barrier Reef, although other varieties are also present as well. It bears numerous small, crowded polyps throughout the body.

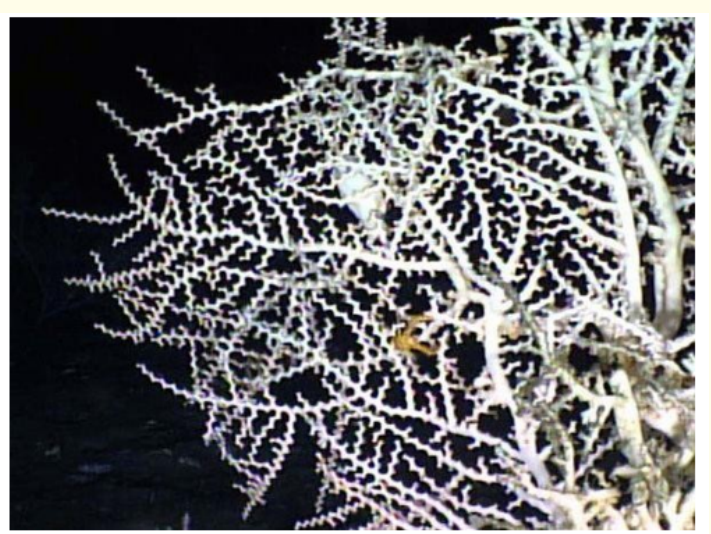

Figure 5

Source: Wikipedia.

Astraea

They are commonly known as star-corals, and they are also the primary reef builders. They appear as mottled or uniform green and brown with darker callices. They are quite uncommon [4].

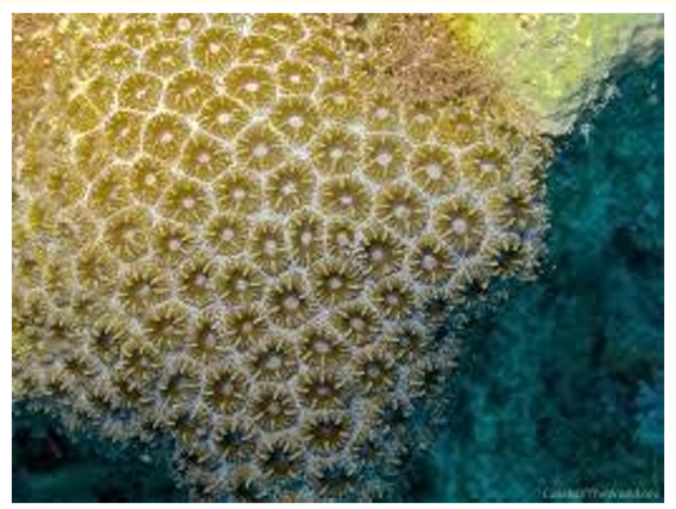

Figure 6: Picture credits: Russell Kelley, Rachel Pears, Phil Woodhead.

\section{Meandrina}

They are commonly known as brain coral. They grow at the same spot for several generations and hence they cover huge areas of the ocean floor. They can also weigh about a ton. When they die, their surface becomes more prominent, and we see why they 
are named as so. They contain deep grooves and crevices on their surface [1].

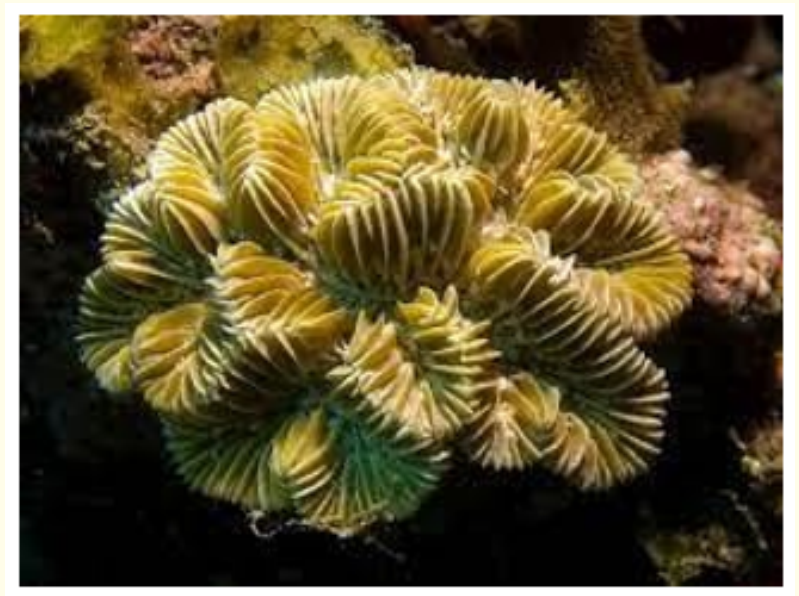

Figure 7

Source: Wikipedia.

\section{Tubipora}

These are also referred to as organ-pipe coral. They belong to the order Stolonifera. The skeleton consists of spicules of $\mathrm{CaCO}_{3}$ fitted together very closely to form vertical tubes, one tube for each polyp which are united by transverse platforms. The skeleton is dull red due to presence of iron salts. Skeleton remains internal during living stage. They form extensive platforms with one another [5].

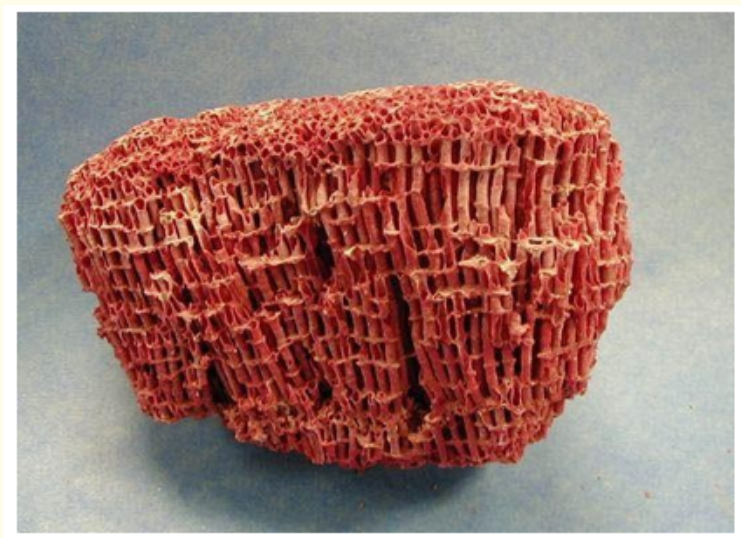

Figure 8

\section{Gorgonia}

They are commonly known as sea fans. They are found around the reefs, but they do not aid in reef formation. They belong to group of soft corals. There are many branches arising from a single stalk and all those branches are joined together to form a mesh. They don't contain $\mathrm{CaCO}_{3}$ and hence they, sway beautifully in the ocean currents [5]. They are usually frequented by dolphins because they are said to contain certain antiseptic properties.

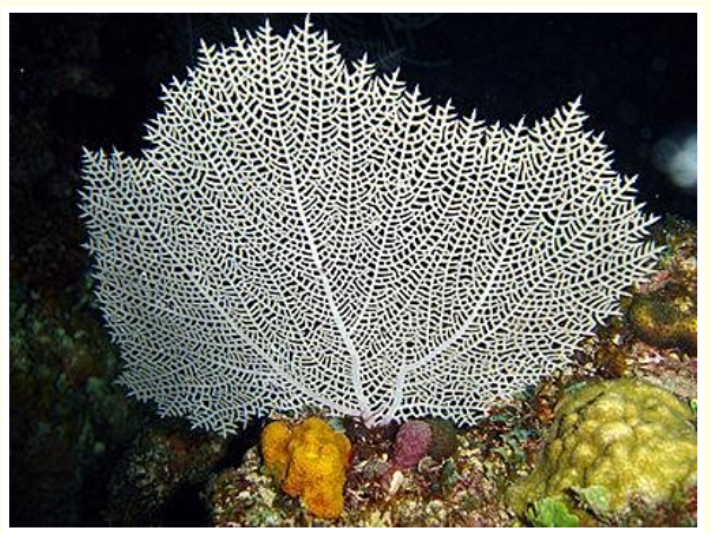

Figure 9

Source: Wiki-educator E-learning content.

\section{Metridium}

It belongs to the same class as corals. The only difference that exists between them and corals is that they do not contain $\mathrm{CaCO}_{3}$. When they die, they decompose and eventually mis with the ocean floor. But corals leave an imprint. They contain special stinging cells called nematocysts which is the characteristic feature of the phylum Cnidaria. They are found attached to rocks and dead corals in the shallow waters. They are usually solitary living, but they can also be found clustered together. Sometimes they develop mutualistic behaviour with the hermit crabs and found attached on their shells.

As all gardens are frequented by visitors, so does the gardens of the sea. The reefs are home to a wide variety of organisms like the fish, molluscs, worms, crustaceans, echinoderms, sponges, etc. All these animals work together to maintain the balance of the ecosystem and help in cleaning and recycling of the items as well. 


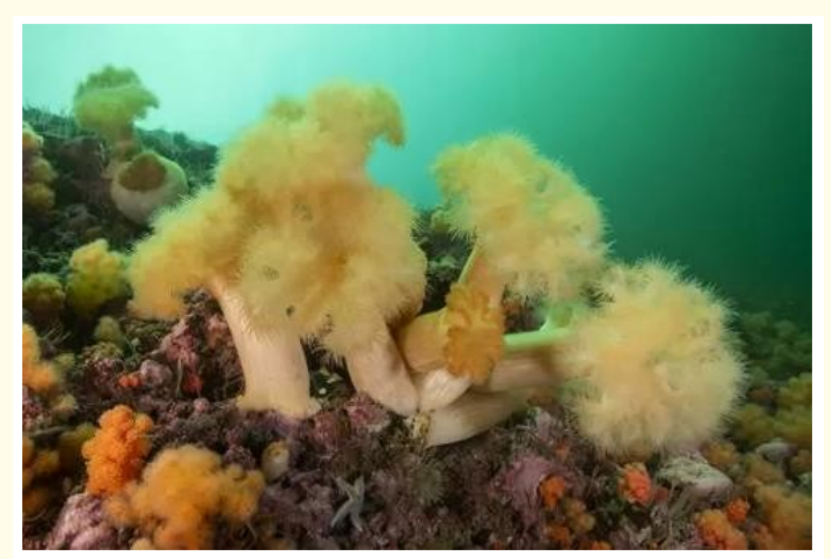

Figure 10

Source: Mediashorehouse.co.

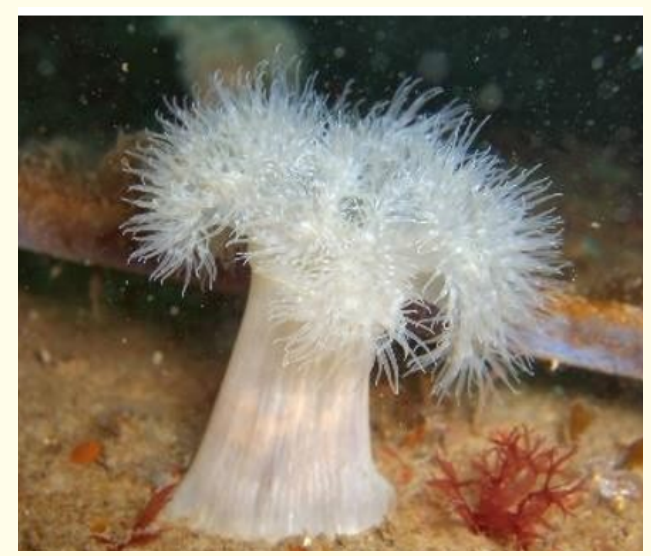

Figure 11

Source: Wikipedia.

Along with corals, there are many different varieties of sponges present. Their bodies are either made up of calcium or of silica. They are pore-bearing organisms. They inhabit wide range of ocean habitats from polar to the tropical regions. The glass rope sponges are mainly could in the deep water whereas the calcareous sponges are found in the shallow waters.

\section{Sponges}

\section{Giant barrel sponge}

They are barrel-shaped in appearance and contain a very large osculum. They are the largest sponge of their variety, and they are home to different fishes.

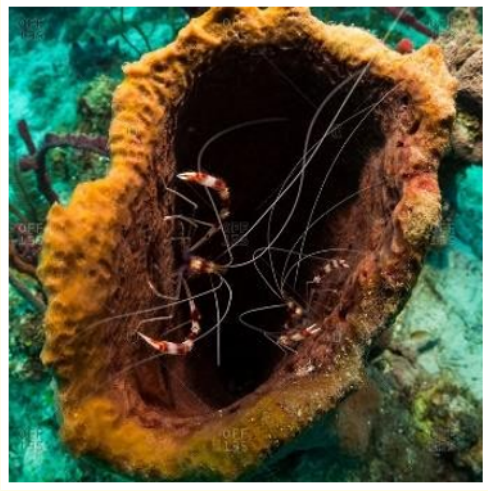

Figure 12: Residents of Barrel Sponge (Shutterstock, n.d.).

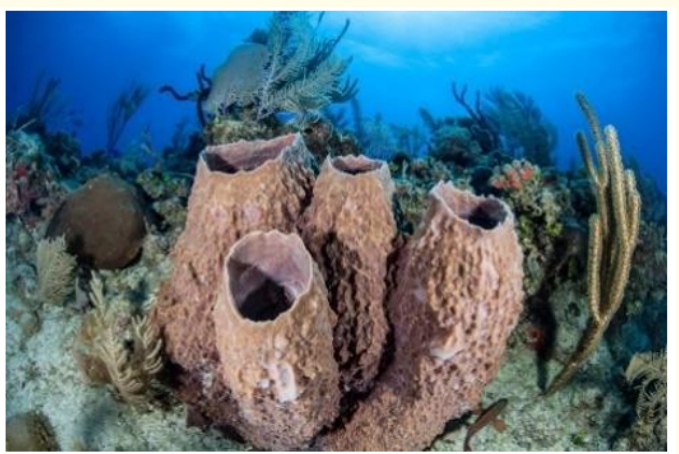

Figure 13: Oceana- Protecting the World's Ocean, n.d..

Tube sponges

Tube sponges mostly the yellow tube sponge live on reefs and are common in the Caribbean, Florida and the Gulf of Mexico. In shallow waters they are mostly yellow in colour but in deeper waters they are darker in colour. They are mostly filter feeders and can reach up to a height of 3 feet [7].

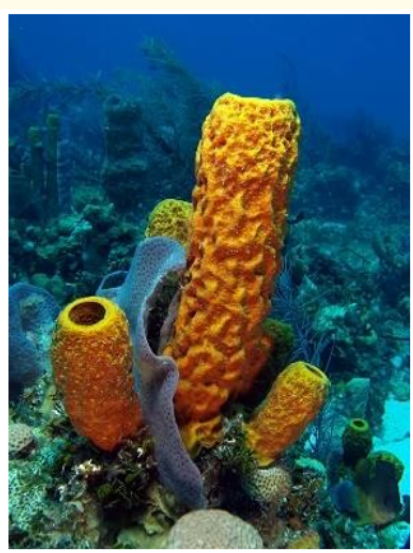

Figure 14: Wikipedia.org. 


\section{Marine fishes}

Many exotic and beautiful variety of marine fishes are found particularly in the reefs. Some are discussed below.

\section{Bartlett's anthias}

This is a ray-finned fish that belongs to the class Actinopterygii and order Perciformes. The fish was first discovered in the Kwajalein Atoll in the Marshall Islands in the Western Pacific Ocean. It is a beautiful fish with lavender colour body and a bright yellow dorsal fin and tail. The underside of the fish is faded purple. But in some cases, it appears bluish. There are different colours of this variety of fish are present. This animal is of least concern as of now, as stated by the IUCN. Its home is in the reefs and is mostly an ornamental fish that is kept in aquariums. Then max length is around $9 \mathrm{~cm} \mathrm{[1].}$
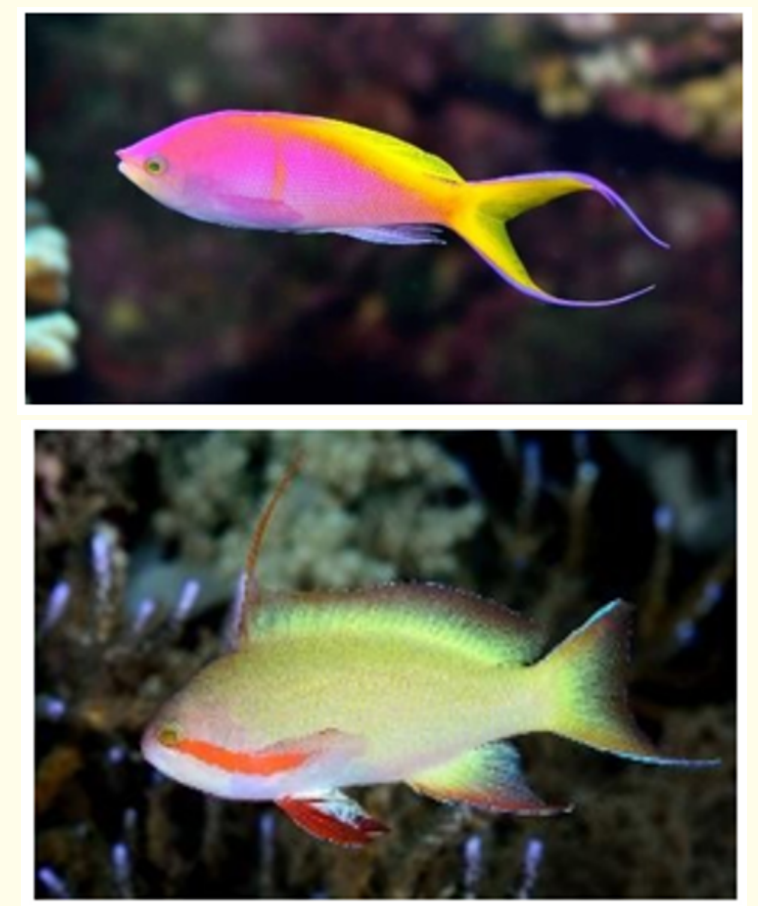

Figure 15: Different shades of Bartlett.

\section{Clown/anemone fish}

This fish is most popularly known as Nemo as it is depicted as the main character of the Disney movie 'Finding Nemo'. It belongs to the same class as Bartletts Anthias and belongs to the sub family of Amphiprioninae. It is found in the warm waters of the Indian ocean including the Great Barrier Reef, Red Sea, and around Japan, to name a few. Warm waters enable the growth of corals and sea anemones. These fishes are in a mutual relationship with the sea anemones where the sea anemone protects the fish. Clownfish, in turn, attracts small fishes due to their vibrant colours, which can then be eaten by the anemones. They range from variety of different colours like yellow, orange, red, and black in colour. They show white banding pattern on their body. They can grow up to 4.3 inches.

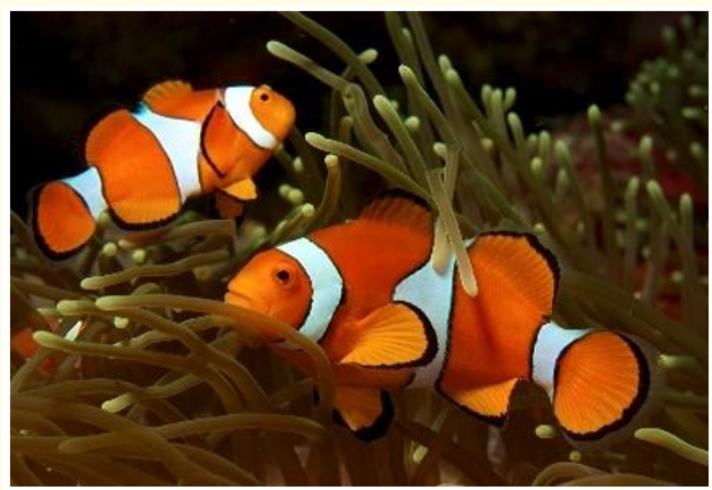

Figure 16: Wikipedia.org, n.d..

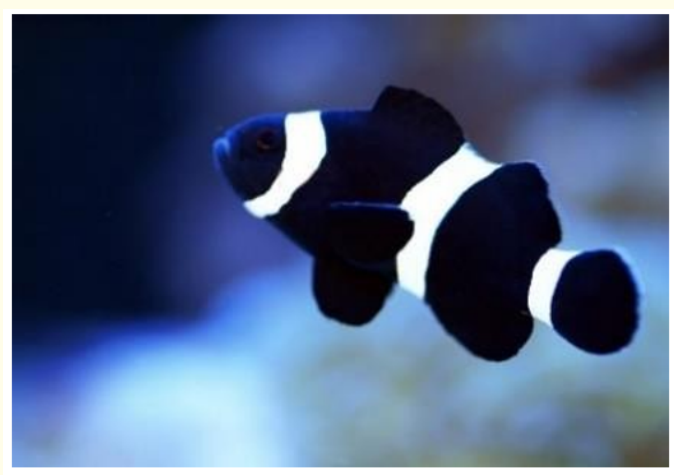

Figure 17:

Source: Pinterest.

\section{Banded pipefish}

These fishes are residents of small caves in the reefs, and they are shy. They have bright red or yellow body with white stripes. They were first discovered by Regan from Mauritius [9]. They are mainly found around the Pacific region of Australia, Fiji, Japan and Indonesia etc. They are cousins of seahorses, and they eat copepods. Very less is known about the fish since they are very shy.

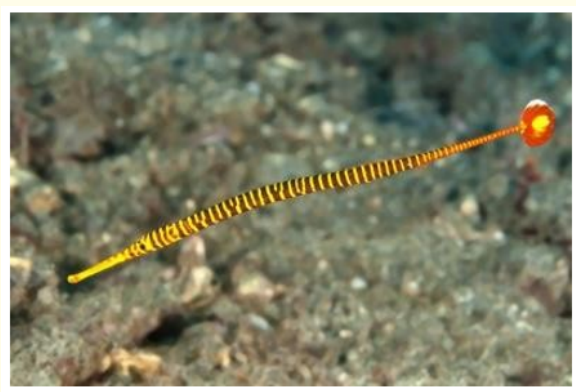

Figure 18: Picture of Banded Pipefish (Wikipedia.org,). 


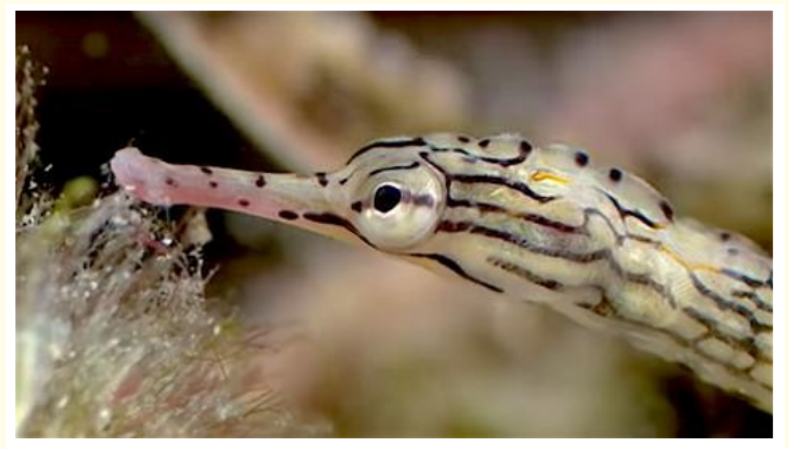

Figure 19: Cousins of seahorses (Adams, 2017).

Moorish idol

These fishes belong to the group of Acanthuriformes. They have somewhat flattened body with black or white snout, and blue strips present. They have a philomantis extension trailing behind them from their dorsal fin. They are mainly found in flat reefs viz. East Africa, Hawaii, Southern Japan, Indian Ocean [1]. They can be kept in aquariums, but it can be very difficult to care for them. They got their names from the Moors of Africa, who believed that they were the bringer of happiness [1].

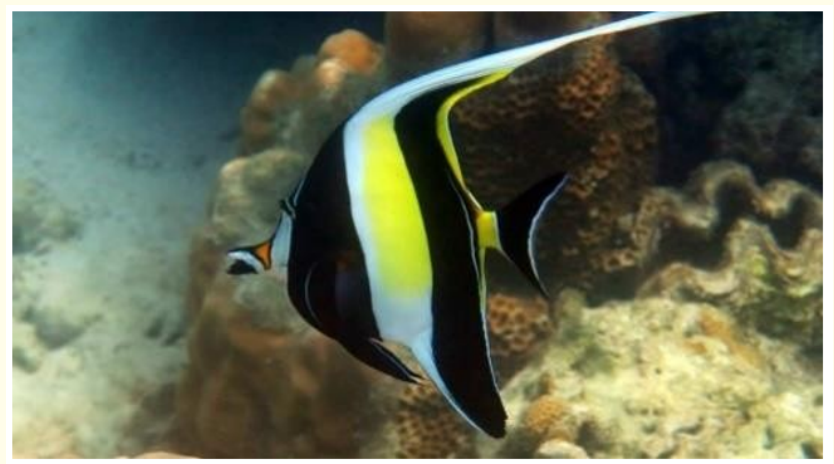

Figure 20: Picture of a Moorish Idol (sanookscuba.com, 2020).

\section{Echinoderms}

Many animals from the phylum Echinodermata are also associated with the reefs and they help in increasing the beauty.

Sea lilies

These belong to the class of Crinoidea. The term 'Crinoidea' comes from the Greek term 'Krinen' meaning lily. The ones that have stalk are called sea-lilies while the ones without stalk are called feather-stars. They contain many arms and from these arms arise many small, slender branches arise. The stalked ones appear as plants, but they are all animals.
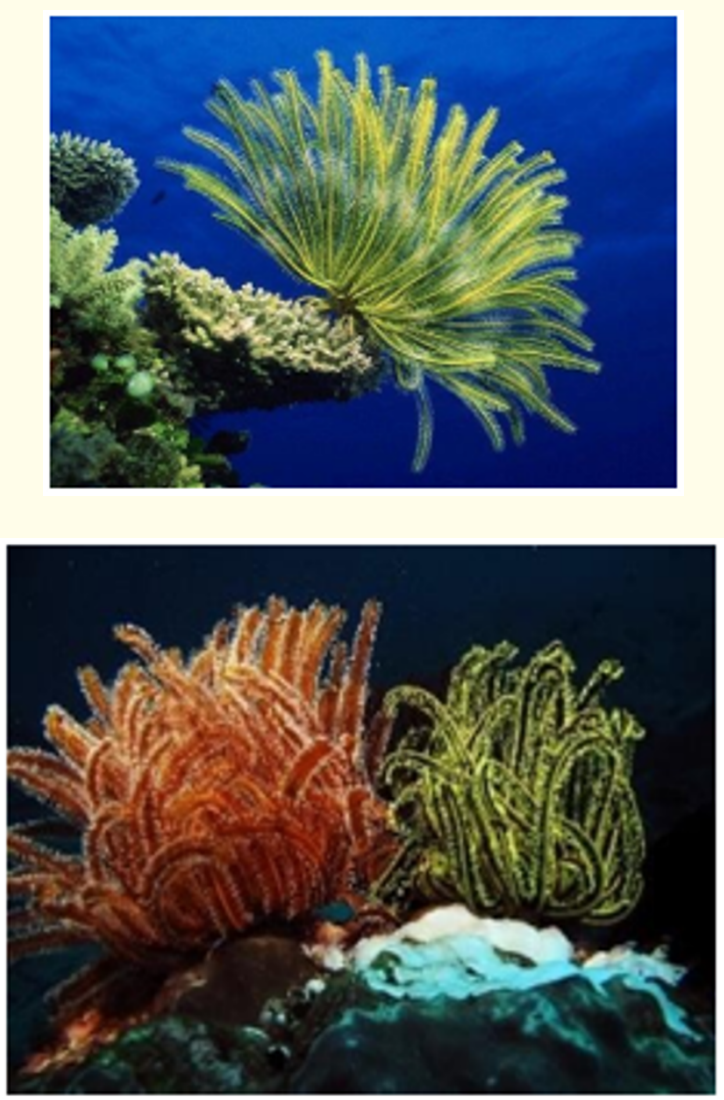

Figure 21: Pictures of sea lilies and feature.

\section{Star fishes}

Although, we call them star fishes, they do not look like fishes at all.With their star shaped body, they are the most common inhabitant of the reefs. With their suckers and tube feet, they can easily walk on the ocean floor.

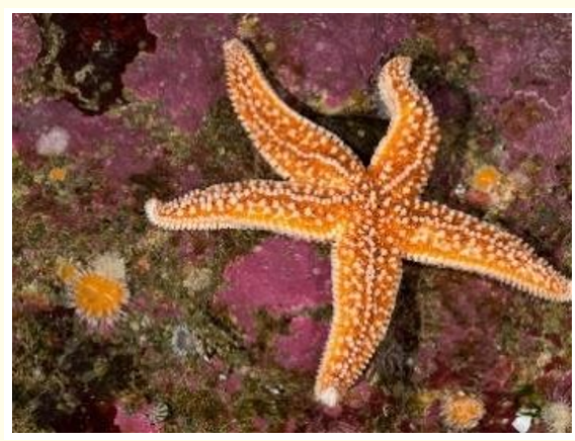

Figure 22: A picture of a starfish. Photo: Alamy Stock photo. 


\section{Molluscs}

The reefs are frequented by molluscs the most. Even though some of them spend their time in the deeper parts of the ocean still they come out to prey on small fishes that reside in the tropics. These include clams, oysters, squid, octopuses etc.

\section{Cuttle fishes}

These animals are found around in the reefs because their favourite food is crabs. They use the hypnotising technique to hunt their prey down. They can change their skin colours, thanks to their chromatophores. Their brain size is quite larger than the body. They contain an endoskeleton that is used as a rich food source of calcium for pet birds. When these animals are threatened, they throw ink and escape.

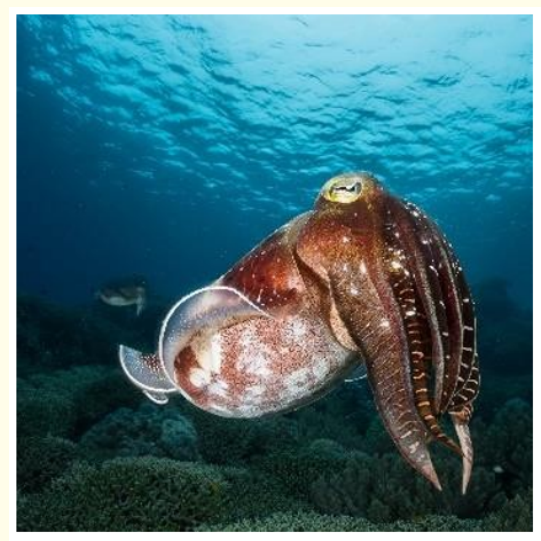

Figure 23: Picture of a cuttlefish (National Geographic, n.d.). Photo by Greg Lecoeur.

\section{Octopus}

This animal is also referred to as the devil fish. It is found in both deepas well as shallow waters. They are soft bodied organisms, and they are also covered in chromatophores with which they change colours according to the environment that is, they can easily camouflage. They are benthic hunters and mainly occur in crevices.

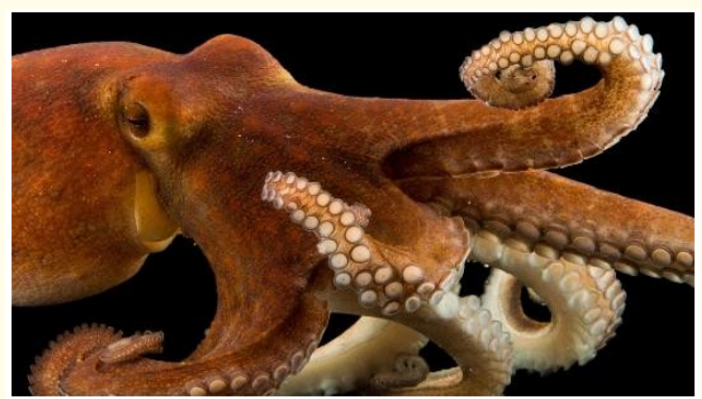

Figure 24: Picture of an octopus. (National Geographic, n.d.). Picture by: Joel Sartore.

\section{Nautilus}

These beautiful creatures are considered to the living fossils and hence, they come under the endangered category. They mainly inhabit the depths of several hundred metres. They are only found in the Indo-Pacific region.

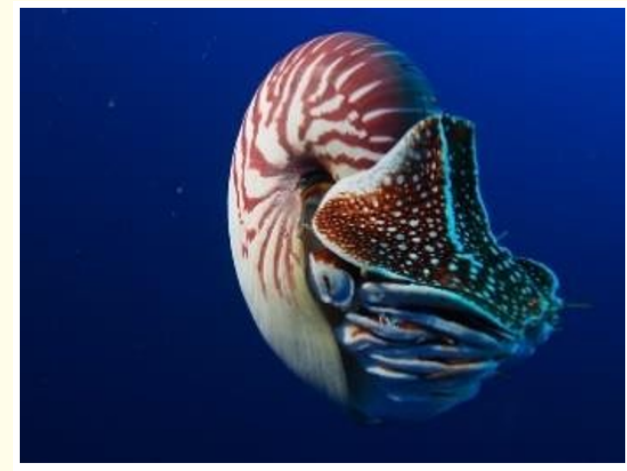

Figure 25: A picture of a Nautilus.

Save the reefs

It is said that life first originated in the waters. Indeed, about $70 \%$ of the earth's surface is covered with water but we know so little about them. The oceans house most of the animal diversity present on our planet. Though man has already visited the Moon and Mars and written long transcripts about the planets of the outer space, he still does not know what is present in the deepest ocean.

The reefs are like oases in the vast blue desert and hence they house about $25 \%$ of the entire diversity of animals present in the sea. They are the major ecosystem of the sea on we as humans are also dependent upon.

Nowadays, the reefs are being subjected to bleaching due to increase in water temperature, $\mathrm{pH}$ and added chemicals. Even the cases of biomagnifications are also increasing.

With the combined efforts from the government and local public, the ocean is now being protected against pollutions. But still more efforts must be made in order to keep the coral reefs as they are now, for future generations. We should all pledge to protect our reefs so that the balance will be maintained, and the garden and the gardeners will flourish.

\section{Bibliography}

1. Wikipedia.org

2. sanookscuba.com

3. Adams J. "Reef Builders". (2017). 
4. Haime ME. "Corals of the World” (1849).

5. Kotpal R L. "Modern Textbook of Zoology". Rastogi Publications (2018-2019).

6. National Geographic (n.d.).

7. Oceana- Protecting the World's Ocean. (n.d.).

8. Shutterstock Ob. (n.d.). Offset by Shutterstock.

9. Sutton A. "Seaunseen" (2020).

\section{Assets from publication with us}

- Prompt Acknowledgement after receiving the article

- Thorough Double blinded peer review

- Rapid Publication

- Issue of Publication Certificate

- High visibility of your Published work

Website: www.actascientific.com/

Submit Article: www.actascientific.com/submission.php

Email us: editor@actascientific.com

Contact us: +919182824667 